\title{
Unheeded biodiversity: perspectives of DNA barcoding of Trichoptera in Bosnia and Herzegovina
}

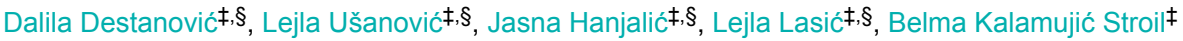 \\ ‡ University of Sarajevo- Institute for Genetic Engineering and Biotechnology, Sarajevo, Bosnia and Herzegovina \\ $\S$ Society for Genetic Conservation of Bosnia and Herzegovina's Endemic and Autochthonous Resources - GENOFOND, \\ Sarajevo, Bosnia and Herzegovina
}

Corresponding author: Dalila Destanović (dalila.destanovic@ingeb.unsa.ba)

Received: 20 Feb 2021 | Published: 04 Mar 2021

Citation: Destanović D, Ušanović L, Hanjalić J, Lasić L, Kalamujić Stroil B (2021) Unheeded biodiversity: perspectives of DNA barcoding of Trichoptera in Bosnia and Herzegovina. ARPHA Conference Abstracts 4: e64709. https://doi.org/10.3897/aca.4.e64709

\begin{abstract}
Bosnia and Herzegovina has valuable natural resources with a high percentage of endemic and autochthonous species (Kučinić et al. 2008, Đug and Drešković 2012). The freshwater fauna of Trichoptera in this area is under-investigated, with a lack of morphological description of different life stages and DNA barcode data. Public data show 58,993 barcode entries for Trichoptera in the Barcode of Life Data Systems (BOLD) submitted from 92 countries, and none from Bosnia and Herzegovina (B\&H) (BOLD 2021). Previous research in Bosnia and Herzegovina has provided the first DNA barcode for the endemic species Rhyacophila bosnica, stored in GeneBank, under accession number MK211322 by a domestic institution (Kalamujić Stroil et al. 2018). A few DNA barcodes of adult individuals of Trichoptera from Bosnia and Herzegovina were found in BOLD. However, these specimens were collected on B\&H territory, but analyzed, processed, and stored by foreign institutions. To change the current state of DNA barcoding of Trichoptera in Bosnia and Herzegovina, we aimed to employ this approach in investigating caddisflies in selected habitats in the Sarajevo Canton.
\end{abstract}

Our fieldwork was done in all five protected areas (spring of the Bosna River, Bijambare, Trebević, Skakavac, and Bentbaša) in which larvae samples were collected according to 
the AQEM sampling methodology. The standard animal DNA barcode was successfully obtained using degenerated primers LCO1490- JJ and HCO2198-JJ (Astrin and Stüben 2008).

Out of 684 collected individuals (313 Trebević, 130 spring of the Bosna River, 117 Bijambare, 71 Bentbaša, 53 Skakavac), a subset of specimens were sequenced. We uncovered 14 different taxa, 11 genera and six families (Limnephilidae, Glossosomatidae, Rhyacophilidae, Goeridae, Hydropsychidae, Polycentropodidae). The preliminary data of Trichoptera composition in the Sarajevo Canton indicated species richness. Based on our sequential data, a new subspecies was discovered in two investigated areas (Valladolid et al. 2020), proving that Trichoptera species diversity in our country is far from entirely uncovered. The benefit and power of the DNA barcoding approach are that it can pinpoint the areas of vast and unknown species diversity more economically, both financially and temporarily, than the morphological approach. Therefore, we believe that it is critical to support the development of DNA barcoding for the bioassessment of freshwater ecosystems in Bosnia and Herzegovina.

Several problems prevented us from exploiting sequential data to the fullest. Despite a general notion among scientists that European Trichoptera species are well covered in the BOLD database, most of the sequences we obtained were absent from the database. Secondly, we recognized that morphological data about the larval developmental stage of B\&H Trichoptera species are largely missing. The unified, updated, and complete data on this order of insects is urgently needed. However, insufficient financial support by governmental institutions and lack of systematic approach to barcoding the wildlife of Bosnia and Herzegovina hampers this process.

Further attempts to collaborate with the stakeholders can be crucial with profound and substantial implications for biomonitoring of aquatic macroinvertebrates in general. New approaches, such as novel DNA barcoding-based methodology can fill an important gap in our knowledge of Balkan caddisflies haplotypes, lineages, and their diversification and distribution patterns.

\section{Keywords}

Trichoptera, Bosnia and Herzegovina, DNA barcoding

\section{Presenting author}

Dalila Destanović

\section{Presented at}

1st DNAQUA International Conference (March 9-11, 2021) 


\section{References}

- $\quad$ Astrin J, Stüben P (2008) Phylogeny in cryptic weevils: molecules, morphology and new genera of western Palaearctic Cryptorhynchinae (Coleoptera:Curculionidae). Invertebrate Systematics 22 (5). https://doi.org/10.1071/is07057

- BOLD (2021) Barcode of Life Data Systems. v4. URL: https://www.boldsystems.org/ index.php

- $\quad$ Đug S, Drešković N (2012) Nature protection in Bosnia and Herzegovina: State and perspectives. Journal for Geography 7.

- Kalamujić Stroil B, Lasić L, Hanjalić J, Mačar S, Vesnić A (2018) The first DNA barcode record for Rhyacophila bosnica Schmid, 1970 and pairing of adult and larval life stages. Genetics \& Applications 2 (2). https://doi.org/10.31383/ga.vol2iss2pp20-27

- Kučinić M, Previšić A, Gottstein S, Hrašovec B, Stanić-Koštroman S, Pernek M, Delić A (2008) Description of the larvae of Drusus radovanovici septentrionis MarinkovicGospodnetic, 1976 and Drusus croaticus Marinkovic-Gospodnetic, 1971 (Trichoptera: Limnephilidae) from Bosnia and Herzegovina, and Croatia. Zootaxa 1783 (1). https:// doi.org/10.11646/zootaxa.1783.1.1

- Valladolid M, Kučinić M, Arauzo M, Cerjanec D, Ćuk R, Dorda B, Lodovici O, StanićKoštroman S, Vučković I, Rey I (2020) The Rhyacophila fasciata Group in Croatia and Bosnia and Herzegovina: Rhyacophila f. fasciata Hagen 1859 and the description of two new subspecies, Rhyacophila fasciata delici Kučinić \& Valladolid (ssp. nov.) from Croatia and Bosnia and Herzegovina and Rhyacophila fasciata viteceki Valladolid \& Kučinić (ssp. nov.) from Bosnia and Herzegovina (Trichoptera: Rhyacophilidae). Zootaxa 4885 (1). https://doi.org/10.11646/zootaxa.4885.1 